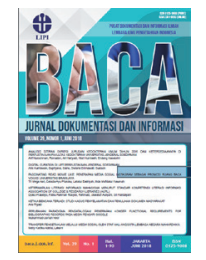

\title{
Analisis tematik artikel dalam jurnal IFLA edisi special issue: knowledge management and library innovation in a changing world
}

\author{
Rizki Nurislaminingsih ${ }^{1 *}$; Sukaesih²; Neneng Komariah ${ }^{3}$ \\ 1,2,3Fakultas Ilmu Komunikasi Universitas Padjadjaran \\ "Korespondensi: rizkinurvega@gmail.com
}

Diajukan: 01-01-2021; Direview: 02-03-2021; Diterima: 21-04-2021; Direvisi: 06-01-2021

\begin{abstract}
This study aims to map the themes discussed in the articles of the IFLA Journal. This study is qualitative with a theme-based approach. The data collection method is text documents analysis. The selected documents were analyzed using ATA (Applied Thematic Analysis). The results showed that IFLA Journal Vol.46, No.1, March 2020 edition of the Special Issue: Knowledge Management and Library Innovation in a Changing World contains articles with 8 themes, namely library assignments in knowledge management, knowledge management in academic libraries, library restructuring by applying knowledge management principles, knowledge management in college libraries, problems that occur after the implementation of knowledge management, city library networks based on the concept of knowledge management, knowledge sharing activities within institutions, and the weakening of library functions if they do not apply the concept of knowledge management. The results of this study show that the articles published in the journal have the theme of adapting the principles of knowledge management in academic and city library activities along with constraints to alternative solutions. This journal also provides an overview of the problems that will occur if the library has not implemented knowledge management.
\end{abstract}

\begin{abstract}
ABSTRAK
Penelitian ini bertujuan untuk memetakan tema yang dibahas dalam artikel Jurnal IFLA. Penelitian ini merupakan penelitian kualitatif dengan pendekatan berbasis tema. Metode pengumpulan data dilakukan dengan cara analisis dokumen teks. Isi dokumen kemudian dianalisis menggunakan ATA (Applied Thematic Analysis). Hasil penelitian menunjukkan bahwa Jurnal IFLA Vol.46, No.1, Maret 2020 edisi Special Issue: Knowledge Management and Library Innovation in a Changing World memuat artikel dengan 8 tema yaitu tugas perpustakaan dalam manajemen pengetahuan, manajemen pengetahuan di perpustakaan akademik, restrukturisasi perpustakaan dengan menerapkan prinsip manajemen pengetahuan, manajemen pengetahuan di perpustakaan perguruan tinggi, masalah yang terjadi pasca implementasi manajemen pengetahuan, jejaring perpustakaan kota berdasarkan konsep manajemen pengetahuan, kegiatan berbagi pengetahuan dalam internal institusi, dan melemahnya fungsi perpustakaan bila tidak menerapkan konsep manajemen pengetahuan. Hasil penelitian menunjukkan bahwa artikel yang termuat pada jurnal tersebut memiliki tema adaptasi prinsip manajemen pengetahuan pada kegiatan perpustakaan akademik dan perpustakaan kota beserta kendala hingga alternatif solusinya. Jurnal ini juga memberi gambaran masalah yang akan terjadi bila perpustakaan belum menerapkan manajemen pengetahuan.
\end{abstract}

Keywords: IFLA journal; Thematic analysis; Knowledge management; Library innovation; Academic library

\section{PENDAHULUAN}

Manajemen pengetahuan merupakan aktivitas mengelola pengetahuan. Pengetahuan diyakini sebagai modal intelektual untuk terus berinovasi menciptakan produk yang bernilai jual tinggi oleh para ahli ekonomi. Aghoghovwia (2014) berpendapat konsep manajemen pengetahuan dimulai dan dipopulerkan di dunia bisnis selama dekade terakhir abad 20, dan pengetahuan dianggap sebagai 
modal utama untuk menjalankan bisnis sehingga memperoleh keunggulan kompetitif. Poonkothai (2016) menjelaskan bahwa Peter Drucker pada tahun 1965 telah menyadari peluang pengetahuan yang kelak akan menggantikan nilai tanah, tenaga kerja, modal finasial hingga kehebatan mesin. Pengetahuan akan berperan menjadi sumber utama produksi. Namun, pandangan Peter Drucker tersebut tidak mendapat banyak perhatian para ahli pada saat itu. Manajemen pengetahuan menjadi terkenal setelah Ikujiro Nonaka memperkenalkan konsep "Spiral of Knowledge" pada tahun 1991 - konsep ini menjadi cikal bakal perkembangan manajemen pengetahuan dalam dunia kerja.

Syahputra \& Munadi (2011) mengatakan bahwa manajemen pengetahuan sesungguhnya telah ada sejak tahun 1960-an, misalnya Polanyi tahun 1966 yang membagi pengetahuan menjadi dua jenis, yaitu tacit (pengetahuan abstrak dalam ide/pikiran individu) dan explicit (pengetahuan terdokumentasi atau terekam dalam benda). Karl-Erik Sveiby menganalisis manajemen pengetahuan di akhir tahun 1980-an dengan fokus penilaian pengetahuan sebagai aset tak terlihat mata namun bernilai sangat berharga. Nonaka dan Takeuchi mengkaji tentang manajemen pengetahuan dalam bidang ekonomi pada 1990-an, hingga mereka ahli dalam penerapan manajemen pengetahuan di perusahaan, pabrik, industri, dan lembaga profit lainnya. Islam et al. (2015) mengatakan bahwa pada 1990-an, konsep manajemen pengetahuan memang berkembang pesat di bidang bisnis.

Konsep manajemen pengetahuan kini telah diadaptasi oleh bidang pendidikan, termasuk di sekolah ilmu perpustakaan dan sains informasi. Aghoghovwia (2014) berpendapat bahwa manajemen informasi telah lama dikenal sebagai domain pustakawan dan perpustakaan. Profesional informasi dan pustakawan dilatih untuk menjadi ahli dalam pencarian, pemilihan, perolehan, pengorganisasian, pelestarian, pengemasan ulang, penyebaran, dan pelayanan informasi. Ia menyarankan perlu ada peran baru perpustakaan di abad ke-21 yakni sebagai pusat pembelajaran dan pengetahuan bagi penggunanya.

Manajemen pengetahuan di perpustakaan dapat meningkatkan peran perpustakaan sebagai pengelola pengetahuan, bukan penyimpan pengetahuan. Perpustakaan masih dipersepsikan sebagai tempat penyimpanan benda fisik yang berisi pengetahuan seperti buku, jurnal, atau karya tulis lainnya. Islam et al. (2015) menjelaskan bahwa penggunaan dan penerapan manajemen pengetahuan masih didominasi oleh organisasi bisnis, meski kini juga telah diterapkan dalam perpustakaan dan ilmu informasi. Persepsi profesional informasi tentang konsep manajemen pengetahuan masih tergolong sempit karena terfokus pada pengelolaan pengetahuan eksplisit. Beberapa profesional informasi yang terlibat dalam praktik manajemen pengetahuan masih menganggap kegiatan ini sebagai bagian dari pengelolaan informasi dasar yang fokus pada manajemen dokumen.

Husain \& Nazim (2013) menjelaskan bahwa The International Federation of Library Associations and Institutions (IFLA) memaknai manajemen pengetahuan sebagai proses menciptakan (generalisasi, menangkap), menyimpan (melestarikan, mengorganisasikan, mengintegrasikan), berbagi (mengomunikasikan), menerapkan (implementasi), dan menggunakan kembali (transformasi) pengetahuan di sebuah organisasi untuk mencapai tujuan tertentu. Penjelasan IFLA tersebut menjadi dasar penerapan manajemen pengetahuan dalam bidang perpustakaan dan sains informasi.

Penerapan manajemen pengetahuan oleh IFLA diperkuat dengan adanya edisi penerbitan jurnal yang khusus membahas hal tersebut. IFLA telah menerbitkan jurnal Special Issue: Knowledge Management and Library Innovation in a Changing World pada Vol.46, No.1, Maret 2020. Terbitan dengan edisi khusus tersebut menarik minat peneliti untuk mengkajinya lebih jauh. Penelitian ini bertujuan untuk memetakan tema yang dibahas dalam Jurnal IFLA Vol.46, No.1, Maret 2020 edisi Special Issue: Knowledge Management and Library Innovation in a Changing World. Peneliti berharap mendapatkan informasi baru tentang penerapan konsep manajemen pengetahuan yang tepat di bidang perpustakaan. 


\section{TINJAUAN PUSTAKA}

Gonzalez \& Martins (2014) memberi contoh tokoh yang menganalisis manajemen pengetahuan dari berbagai keilmuan, seperti Poynder (1998) yang menekankan posisi manajemen pengetahuan dalam teknologi informasi. Baginya produk teknologi sangat berperan dalam alur aktivitas manajemen pengetahuan. Swan et al. (1999) lebih berfokus pada model manajemen pengetahuan yang berbasis komunitas, bukan teknologi. Tujuan dari model ini adalah eksplorasi pengetahuan pada interaksi antara individu dengan sesamanya.

Alvesson \& Kärreman (2001) menilai bahwa komunitas lebih mudah mempraktikkan manajemen pengetahuan saat mereka berinteraksi langsung untuk berbagi ide. Kajian manajemen pengetahuan dalam berbagai disiplin ilmu juga diakui oleh Heisig (2009); Bedford \& Lewis (2015) bahwa bidang ekonomi, bisnis, artificial intelligence, ilmu pengetahuan kognitif hingga linguistik telah mempelajari manajemen pengetahuan. Seluruh disiplin ilmu tersebut bahkan telah memiliki teori dan model manajemen pengetahuan yang sesuai bidang masing-masing.

Islam et al. (2015) menjelaskan istilah pengetahuan mengacu pada kumpulan informasi yang memiliki makna, dapat dipahami, dan berguna untuk pengambilan keputusan. Informasi tidak semata-mata berarti pesan yang didapat oleh seseorang. Jika informasi yang didapat tidak dimaknai dan tidak digunakan untuk menentukan sikap, maka informasi tetaplah informasi, maka belum berubah menjadi pengetahuan. Manajemen pengetahuan merupakan proses yang mengatur penciptaan, penyebaran dan pemanfaatan pengetahuan sehingga tepat sasaran. Manajemen pengetahuan dapat disebut sebagai sistem atau disiplin ilmu yang mengatur layanan informasi agar berubah menjadi pengetahuan bagi penggunanya.

Foo et al. (2002) \& Islam et al. (2015) menjelaskan bahwa pustakawan sebagai pekerja pengetahuan perlu memainkan peran aktif dalam mencari solusi inovatif untuk masalah yang mereka hadapi. Manajemen pengetahuan membuat pustakawan mampu beradaptasi dengan lingkungan baru. Riyadi, Mahmudah, \& Utami (2016) berpendapat bahwa manajemen pengetahuan terus berkembang tidak hanya pada ranah industri tetapi juga di lembaga dokumentasi dan informasi. Poonkothai (2016) yang menjelaskan bahwa kedudukan manajemen pengetahuan dalam perpustakaan dan ilmu informasi diakui Ranganathan (2011) sebagai subjek bidang keilmuan identik dengan pengetahuan, sedangkan aktivitas perpustakaan sendiri lekat dengan pengelompokan dan layanan subjek ilmu.

Aplikasi manajemen pengetahuan dalam bidang perpustakaan didukung oleh IFLA. Sudarsono \& Imadianti (2012) menjelaskan bahwa IFLA telah mengonsep manajemen pengetahuan sejak tahun 2001 dan diresmikan pada 2003 dalam bentuk unit Knowledge Management Section. Unit tersebut berperan sebagai fasilitator pelaksanaan adaptasi manajemen pengetahuan bagi institusi perpustakaan dan lembaga lain yang berada di bawah koordinasi IFLA.

\section{METODE}

Penelitian ini menggunakan desain kualitatif dengan pendekatan berbasis tema yang penulis kutip dari Guest, MacQueen, dan Namey (2012). Pada penelitian ini, Jurnal IFLA diposisikan sebagai dokumen teks. Pengambilan sampel dokumen dilakukan dengan purposive sampling, sehingga memungkinkan peneliti memilih sendiri sampel yang sesuai dengan tujuan penelitian (Silverman, 2014). Purposive sampling berguna ketika tujuan penelitian lebih difokuskan pada organisasi atau proses sosial daripada individu. Keabsahan data pada penelitian mengacu pada pendapat Silverman (2014), bahwa penelitian dokumen teks sudah memiliki data yang siap pakai sehingga secara otomatis dapat dianggap reliable. Tugas peneliti melakukan "inter-rates reliability", yakni menggolongkan data sesuai dengan kategori tema tanpa merubah makna teks.

Pencarian data dilakukan dengan mengetik kata kunci Knowledge Management IFLA di Google. Berdasarkan ketersediaan artikel di website IFLA, peneliti memilih Vol.46, No.1 Maret 2020 yakni 
Special Issue: Knowledge Management and Library Innovation in a Changing World yang berisi 7 artikel. Pemilihan ini didasarkan pada pertimbangan bahwa jurnal edisi khusus merupakan kumpulan artikel yang terdiri atas beberapa tema sejenis yang relevan satu sama lain. Edisi khusus ini menjadi bukti tertulis bahwa ILFA telah mengakui keterkaitan manajemen pengetahuan dengan perpustakaan. artikel Jurnal IFLA yang terkumpul kemudian dianalisis menggunakan ATA (Applied Thematic Analysis).

Data hasil analisis dituliskan dalam bentuk deskriptif. Labra et al. (2020) mengatakan penelitian kualitatif merupakan jenis penelitian yang menjelaskan fenomena dalam masyarakat. Keunggulan kualitatif adalah fleksibilitas dalam menggunakan berbagai teknik penelitian seperti observasi partisipan, metode wawancara, analisis literatur hingga analisis sumber (termasuk dokumen). Matthies \& Coners (2017) bahwa analisis dokumen adalah salah satu metode penelitian sosial kualitatif. Dokumen jenis teks memiliki potensi besar untuk eksplorasi pengetahuan, baik itu yang masih bersifat umum maupun yang sudah spesifik. Para peneliti yang mengkaji manajemen pengetahuan dituntut untuk lebih memperhatikan tentang kualitas dokumen dan seleksi dokumen yang ketat, sehingga sesuai dengan tujuan penelitian.

Analisis dokumen pada penelitian ini dilakukan dengan cara analisis tematik pada teks artikel Jurnal IFLA Vol.46, No.1, Maret 2020 yakni Special Issue: Knowledge Management and Library Innovation in a Changing World. Matthies \& Andre (2017) menggambarkan analisis dokumen sebagai prosedur sistematis untuk meninjau dan mengevaluasi dokumen yang bermedia cetak maupun elektronik (berbasis komputer dan internet). Matthies dan Coners (2017) menambahkan pada posisi ini, dokumen dipahami sebagai sebuah artefak yang fitur utamanya berupa teks tertulis. Dokumen pada konteks ini berupa teks yang tertulis di kertas, tersimpan di komputer atau perangkat teknologi lain.

Analisis dokumen dapat dilakukan dengan tiga cara, yakni kualitatif analisis konten, kuantitatif analisis konten dan analisis tematik. Vaismoradi et al. (2016) menjelaskan penelitian analisis tematik memunculkan inti content yang terpendam dalam teks dan merincinya ke dalam beberapa kategori seperti tema dan subtema. Sebuah teks dapat memiliki lebih dari satu tema dan satu tema juga dapat memiliki lebih dari satu subtema. Setiap tema pada umumnya memiliki subtema sebagai subdivisi yang berfungsi sebagai penjelas tema. Dari tema dan subtema ini kemudian akan memunculkan sebuah pola tematik yang tidak terlihat sebelumnya. Subtema merupakan pecahan dari tema. Subtema tetap memiliki konsep yang sama dengan tema, hanya saja fokus pada satu unsur yang spesifik. Teks mengandung beragam makna yang perlu diidentifikasi dan diuraikan oleh peneliti. Makna dalam teks umumnya dapat digali dalam kategori tema dan subtema. Tema merupakan kata yang memiliki makna konsep, bersifat deskriptor, dan memiliki unsur penjelas.

Guest, MacQueen, \& Namey (2012) mengungkapkan ATA (Applied Thematic Analysis) merupakan jenis analisis induktif data kualitatif yang dirancang untuk mengidentifikasi dan memeriksa tema dari data tekstual secara transparan dan kredibel namun tidak bertujuan membangun teori seperti halnya penelitian gounded theory. ATA lebih tepat digunakan untuk menganalisis topik, mengidentifikasi beragam tema kunci/inti dalam teks daripada analisis pengalaman individu (masyarakat). ATA lebih bersifat fleksibel karena tidak ada aturan baku dalam prosesnya. Keunggulan ATA yaitu fokus pragmatisnya dalam menggunakan alat apapun yang sesuai untuk menyelesaikan pekerjaan analitik secara transparan, efisien, dan etis. ATA bukan menghitung kata atau frasa eksplisit, tapi mengutamakan proses identifikasi dan mendeskripsikan ide implisit dan eksplisit dalam data yang berupa tema. 
Metode ATA dapat dilakukan dengan pencarian kata yang tepat dalam teks, reduksi data, dan mendeskripsikan hasil reduksi. ATA mengidentifikasi tema kunci dalam teks dan mengembangkan code untuk mewakili tema yang diidentifikasi. Tema diubah menjadi code dan digabungkan dalam codebook. Code ini sebagai penanda ringkasan untuk analisis selanjutnya. Vaismoradi, Turunen, \& Bondas (2013) mengatakan bahwa salah salah satu ciri data analisis yang menggunakan teknik analisis tematik adalah terbentuknya pola peta tema mulai dari tema utama (diberi deskripsi singkat), code (kriteria pembentuk tema) hingga penjelasan singkat mengenai hubungan antara tema dan code. Nowell et al. (2017) mengatakan bahwa selama proses code, peneliti mengidentifikasi isu-isu atau bagian penting yang berhubungan dengan tema atau contoh yang relevan.

\section{HASIL DAN PEMBAHASAN}

Berdasarkan hasil pengumpulan data menunjukkan bahwa Jurnal IFLA Vol.46, No.1, Maret 2020 edisi Special Issue: Knowledge Management and Library Innovation in a Changing World terdiri dari 7 judul artikel, sebagaimana terlihat pada Tabel 1.

Tabel 1. Judul Artikel Jurnal IFLA

\begin{tabular}{ll}
\hline No. & Judul Artikel \\
\hline 1 & $\begin{array}{l}\text { From information, to data, to knowledge - digital scholarship centers: An emerging transdisciplinary } \\
\text { digital knowledge and research methods integrator in academic and research libraries }\end{array}$ \\
\hline 2 & $\begin{array}{l}\text { Innovative application of knowledge management in organizational restructuring of academic librar- } \\
\text { ies: A case study of Peking University Library }\end{array}$ \\
\hline 3 & Knowledge management in practice in academic libraries \\
\hline 5 & $\begin{array}{l}\text { City library network knowledge management for social cohesion: The case of Santa Coloma de } \\
\text { Gramenet, Barcelona, Spain }\end{array}$ \\
\hline 7 & Determining the impact of knowledge sharing initiatives in international organizations: Case studies \\
\hline
\end{tabular}
Sumber: Data olah peneliti (2020)

Hasil analisis tema pada ketujuh judul artikel di atas (Tabel 1) yang mengacu pada tema kunci dalam teks dan mengembangkan code (kriteria pembentuk tema) diperoleh codebook berikut ini (Tabel 2).

Tabel 2. Codebook Tema Artikel Jurnal IFLA

\begin{tabular}{|c|c|c|}
\hline Tema & Code & Keterangan \\
\hline \multicolumn{3}{|c|}{$\begin{array}{l}\text { Artikel 1: From information, to data, to knowledge-digital scholarship centers: An emerging transdisci- } \\
\text { plinary digital knowledge and research methods integrator in academic and research libraries }\end{array}$} \\
\hline \multirow[t]{2}{*}{$\begin{array}{l}\text { Tugas perpustakaan dalam } \\
\text { manajemen pengetahuan }\end{array}$} & $\begin{array}{l}\text { Kepustakawanan belum men- } \\
\text { cakup pengelolaan pengeta- } \\
\text { huan tacit. }\end{array}$ & $\begin{array}{l}\text { Kepustakawanan berfokus pada pengetahuan } \\
\text { yang dibuat di tempat lain bukan pada pencip- } \\
\text { taan pengetahuan. }\end{array}$ \\
\hline & $\begin{array}{l}\text { Perpustakaan menge- } \\
\text { lola pengetahuan eksplisit } \\
\text { (manuskrip, buku, jurnal, dan } \\
\text { makalah, hingga gambar dan } \\
\text { video, baik analog maupun } \\
\text { digital). }\end{array}$ & $\begin{array}{l}\text { Pustakawan memainkan peran dominan dalam } \\
\text { mengumpulkan dan mengkurasi pengetahuan } \\
\text { terutama miliki lembaga induk. }\end{array}$ \\
\hline
\end{tabular}




\begin{tabular}{lll}
\hline $\begin{array}{l}\text { Manajemen pengetahuan di } \begin{array}{l}\text { kepustakawanan mengatur, } \\
\text { perpustakaan akademik }\end{array} \\
\text { menyebarkan, dan penyimpa- } \\
\text { nan pengetahuan eksplisit } \\
\text { milik universitas. }\end{array}$ & $\begin{array}{l}\text { Perpustakaan membuat repositori dan men- } \\
\text { gumpulkan grey literature namun belum } \\
\text { memainkan peran penting dalam memberday- } \\
\text { akan produk tersebut. }\end{array}$ \\
\cline { 2 - 3 } $\begin{array}{l}\text { Manajemen pengetahuan } \\
\text { dapat menjadi katalisator } \\
\text { untuk inovasi dalam layanan } \\
\text { perpustakaan. }\end{array}$ & $\begin{array}{l}\text { Mengadopsi praktik manajemen pengetahuan } \\
\text { dapat membantu perpustakaan menjadi lebih } \\
\text { inovatif. }\end{array}$ \\
\cline { 2 - 2 } & $\begin{array}{l}\text { Membuat pusat komunitas dengan fasilitas } \\
\text { digital lengkap yang khusus berfungsi sebagai } \\
\text { tempat untuk menciptakan pengetahuan baru, } \\
\text { berbagi pengetahuan, serta mensosialisasikan } \\
\text { hasilnya ke seluruh sivitas kampus. }\end{array}$ \\
\hline
\end{tabular}

Artikel 2: Innovative application of knowledge management in organizational restructuring of academic libraries: A case study of Peking University Library

\section{Restrukturisasi per-} pustakaan dengan menerapkan prinsip manajemen pengetahuan

\section{Transformasi manajemen} perpustakaan berbasis literature stream atau information stream ke knowledge stream.
Literature stream dan information stream mengacu pada sistem manajemen operasional yang didasarkan pada koleksi seperti layanan teknis (akuisisi, katalogisasi, preservasi) dan layanan pengguna (sirkulasi, referensi, otomasi perpustakaan). Knowledge stream berarti perpustakaan berperan sebagai pusat layanan pengetahuan.

\begin{tabular}{ll}
\hline Manajemen pengetahuan & $\begin{array}{l}\text { Manajemen pengetahuan untuk pengguna } \\
\text { dimulai dari analisis permintaan pemenuhan } \\
\text { kebutuhan hingga penyediaan layanan penge- } \\
\text { tahuan yang tepat. }\end{array}$ \\
\hline Manajemen pengetahuan & $\begin{array}{l}\text { Manajemen pengetahuan internal maksudnya } \\
\text { aktivitas pegawai di perpustakaan menekank- } \\
\text { antuk internal. }\end{array}$ \\
pengetahuan.
\end{tabular}

Artikel 3: Knowledge management in practice in academic libraries

Manajemen pengetahuan di perpustakaan perguruan tinggi
Keahlian manajemen pengetahuan
Strategi untuk melaksanakan manajemen pengetahuan termasuk penggunaan teknologi.

Artikel 4: Problems of knowledge management practices in libraries and information centres of Bangladesh

Masalah yang terjadi pasca Masalah internal

implementasi manajemen

pengetahuan di per-

pustakaan
Kurangnya tata kelola yang baik, krisis keuangan, korupsi, minim teknologi pendukung, hingga kurangnya upaya kolaboratif untuk saling menciptakan dan berbagi pengetahuan antarpustakawan.

Upaya penyelesaian masalah Penggunaan teknologi yang lebih baru, promosikan/beri insentif kepada staf, membentuk tim khusus, pelibatan dalam pelatihan, seminar/lokakarya, penciptaan budaya berbagi pengetahuan. 
Artikel 5: City library network knowledge management for social cohesion: The case of Santa Coloma de Gramenet, Barcelona, Spain

Jejaring perpustakaan kota berdasarkan konsep manajemen pengetahuan
Budaya saling mengumpulkan dan menyimpan pengetahuan eksplisit.

Budaya saling akses dan tukar menukar koleksi

Budaya saling berbagi pengetahuan tacit.
Melalui repositori, pangkalan data atau koleksi cetak.
Membuat komunitas sesuai bidang keahlian, rotasi pelatihan/magang bagi pustakawan di perpustakaan yang berbeda.

\begin{tabular}{|c|c|c|}
\hline \multicolumn{3}{|c|}{$\begin{array}{l}\text { Artikel 6: Determining the impact of knowledge sharing initiatives in international organizations: Case stud- } \\
\text { ies }\end{array}$} \\
\hline $\begin{array}{l}\text { Kegiatan berbagi pengeta- } \\
\text { huan dalam internal institusi }\end{array}$ & $\begin{array}{l}\text { Pelaksanaan berbagi penge- } \\
\text { tahuan }\end{array}$ & $\begin{array}{l}\text { Menyeleksi kapasitas dan kompetensi pega- } \\
\text { wai dalam mengelola konten. Antarpegawai } \\
\text { melakukan kolaborasi kerja, menyamakan } \\
\text { pola pikir dan perilaku dalam aktivitas berbagi } \\
\text { pengetahuan termasuk dengan cara meman- } \\
\text { faatkan perangkat teknologi dan media sosial. }\end{array}$ \\
\hline & $\begin{array}{l}\text { Evaluasi pelaksanaan berbagi } \\
\text { pengetahuan }\end{array}$ & $\begin{array}{l}\text { Dilakukan oleh pimpinan bersama-sama den- } \\
\text { gan anggota dari setiap lini bidang }\end{array}$ \\
\hline
\end{tabular}

\begin{tabular}{lll}
\hline \multicolumn{2}{l}{ Artikel 7: The organizational trap-gap framework: A conceptual view of library dysfunction } \\
\hline $\begin{array}{l}\text { Melemahnya fungsi per- } \\
\text { pustakaan bila tidak mene- } \\
\text { rapkan konsep manajemen } \\
\text { pengetahuan }\end{array}$ & $\begin{array}{l}\text { Masalah yang terjadi adalah } \\
\text { aktivitas internal yang tidak } \\
\text { terorganisir dengan baik }\end{array}$ & $\begin{array}{l}\text { Mempengaruhi produk dan layanan yang } \\
\text { tidak berkembang sesuai tuntutan zaman. }\end{array}$ \\
\cline { 2 - 3 } & Penyebab masalah & $\begin{array}{l}\text { Kurangnya kesadaran untuk mengembangkan } \\
\text { budaya manajemen pengetahuan. }\end{array}$ \\
\cline { 2 - 3 } & Solusi & $\begin{array}{l}\text { Pemimpin mengidentikasi penyebab masalah } \\
\text { kemudian mengembangkan strategi komuni- } \\
\text { kasi. }\end{array}$ \\
\hline
\end{tabular}

Sumber: Data olah peneliti (2020)

Tabel 2 merupakan codebook yang berguna untuk menganalisis inti content yang terinci ke dalam beberapa subtema. Sebuah teks dapat memiliki lebih dari satu tema dan satu tema juga dapat memiliki lebih dari satu subtema. Berdasarkan tema dan subtema ini kemudian akan memunculkan sebuah pola atau alur tematik yang belum terlihat jelas pada artikel aslinya. Hal tersebut terlihat pada Tabel 3.

Tabel 3. Tema dan Subtema Artikel Jurnal IFLA

\begin{tabular}{ll}
\hline Subtema & Keterangan \\
\hline Tema 1: Tugas perpustakaan dalam manajemen pengetahuan \\
\hline Manajemen pengetahuan eksplisit & $\begin{array}{l}\text { Perpustakaan sebagai pengelola pengetahuan yang terekam ke } \\
\text { dalam benda fisik. Perpustakaan belum memainkan peran dalam }\end{array}$ \\
& penciptaan hingga berbagi pengetahuan tacit. \\
\hline
\end{tabular}




\begin{tabular}{ll}
\hline Tema 2: Manajemen pengetahuan di perpustakaan akademik \\
\hline $\begin{array}{l}\text { Manajemen pengetahuan eksplisit yang } \\
\text { ada di universitas }\end{array}$ & $\begin{array}{l}\text { Mulai dari pengetahuan berbentuk fisik tercetak hingga integrasi } \\
\text { pengetahuan berbentuk digital sesuai kebutuhan pengguna. }\end{array}$ \\
\hline $\begin{array}{l}\text { Manajemen pengetahuan sebagai katal- } \\
\text { isator bagi inovasi layanan }\end{array}$ & $\begin{array}{l}\text { Membuat komunitas sebagai wadah untuk menciptakan, menyim- } \\
\text { pan dan berbagi pengetahuan. }\end{array}$ \\
\hline Tema 3: Restrukturisasi perpustakaan dengan menerapkan prinsip manajemen pengetahuan \\
\hline $\begin{array}{l}\text { Peralihan literature stream atau infor- } \\
\text { mation stream ke knowledge stream }\end{array}$ & $\begin{array}{l}\text { Tugas utama perpustakaan adalah layanan pengetahuan (isi intelek- } \\
\text { tual koleksi), bukan semata meminjamkan fisik koleksi. }\end{array}$ \\
\hline $\begin{array}{l}\text { Manajemen pengetahuan untuk ekster- } \\
\text { nal }\end{array}$ & $\begin{array}{l}\text { Penciptaan produk layanan pengetahuan yang inovatif berdasarkan } \\
\text { koleksi yang ada seperti membuat laporan analisis tentang trend } \\
\text { publikasi artikel. }\end{array}$ \\
\hline Manajemen pengetahuan untuk internal & $\begin{array}{l}\text { Pustakawan mampu menyerap pengetahuan yang didapat dari } \\
\text { belajar mandiri/seminar/pelatihan kemudian saling berbagi penge- } \\
\text { tahuan. Selain itu pustakawan juga mampu mengubah pengetahuan } \\
\text { tacit menjadi pengetahuan eksplisit sehingga berguna bagi sesama } \\
\text { pustakawan. }\end{array}$ \\
\hline
\end{tabular}

Tema 4: Manajemen pengetahuan di perpustakaan perguruan tinggi

Keahlian manajemen pengetahuan

Strategi untuk melaksanakan manajemen pengetahuan di setiap divisi atau lini bidang seperti berbagi pengetahuan tacit dalam bentuk percakapan sehari-hari termasuk diskusi, kemudian diperluas dengan penggunaan perangkat teknologi yang kelak dapat menghasilkan pengetahuan eksplisit.

\begin{tabular}{|c|c|}
\hline Masalah internal & $\begin{array}{l}\text { Kurangnya kesadaran untuk membudayakan aktivitas berdasarkan } \\
\text { prinsip manajemen pengetahuan. }\end{array}$ \\
\hline Problem solving & $\begin{array}{l}\text { Pimpinan memberi stimulan bagi pustakawan agar bersedia men- } \\
\text { jalankan kegiatan dengan basis manajemen pengetahuan. }\end{array}$ \\
\hline \multicolumn{2}{|c|}{ Tema 6: Jejaring perpustakaan kota berdasarkan konsep manajemen pengetahuan } \\
\hline $\begin{array}{l}\text { Budaya saling menghimpun dan me- } \\
\text { nyebarkan pengetahuan eksplisit }\end{array}$ & Secara manual atau berbasis teknologi. \\
\hline $\begin{array}{l}\text { Budaya saling menciptakan dan berbagi } \\
\text { pengetahuan tacit }\end{array}$ & Membentuk communities of practice. \\
\hline \multicolumn{2}{|c|}{ Tema 7: Kegiatan berbagi pengetahuan dalam internal institusi } \\
\hline Knowledge sharing & Secara langsung dan berbantukan perangkat digital. \\
\hline Evaluasi kegiatan knowledge sharing & $\begin{array}{l}\text { Mulai dari persiapan, identifikasi, diskusi hingga pembuatan lapo- } \\
\text { ran. }\end{array}$ \\
\hline \multicolumn{2}{|c|}{ Tema 8: Melemahnya fungsi perpustakaan bila tidak menerapkan konsep manajemen pengetahuan } \\
\hline Kinerja pustakawan yang belum terarah & Aktivitas internal yang tidak terorganisir dengan baik. \\
\hline Penyebab utama masalah & $\begin{array}{l}\text { Kurangnya kesadaran untuk mengembangkan budaya manajemen } \\
\text { pengetahuan. }\end{array}$ \\
\hline Dampak & Jenis produk dan layanan yang monoton. \\
\hline Solusi & $\begin{array}{l}\text { Identikasi penyebab masalah kemudian mengembangkan strategi } \\
\text { komunikasi sehingga pustakawan bersedia menerapkan manajemen } \\
\text { pengetahuan. }\end{array}$ \\
\hline
\end{tabular}


Berdasarkan Tabel 3 dapat diketahui bahwa Jurnal IFLA edisi Special Issue: Knowledge Management and Library Innovation in a Changing World merupakan kumpulan artikel yang berisi, contoh studi kasus dan solusi bila terjadi masalah ketika perpustakaan menerapkan prinsip manajemen pengetahuan.

- Artikel pertama, memberikan pemahaman bahwa tugas perpustakaan dalam manajemen pengetahuan masih diposisikan sebagai institusi yang menghimpun pengetahuan yang ada dalam benda terutama produk pengetahuan yang diterbitkan oleh lembaga induk. Tugas perpustakaan fokus pada mengolah pengetahuan eksplisit, belum mengelola pengetahuan tacit transisi antara pengelolaan pengetahuan eksplisit ke tacit dibahas pada artikel kedua.

- Artikel kedua, memberikan gambaran tentang perubahan tugas utama perpustakaan. Pustakawan diharapkan mampu menjadi agen penyebar pengetahuan secara lisan, bukan lagi orang yang mencarikan koleksi kemudian diberikan kepada pemustaka. Pustakawan harus dapat menjadi teman diskusi bagi pemustaka yang membutuhkan koleksi tertentu. Pemustaka benar-benar mendapatkan koleksi yang tepat karena telah mendapat penjelasan singkat isi koleksi.

- Artikel ketiga, memberikan gambaran penerapan konsep manajemen pengetahuan dalam perpustakaan perguruan tinggi.

- Artikel keempat, mencontohkan cara analisis masalah pra-aplikasi dan perubahan yang terjadi saat perpustakaan mulai mengaplikasikan prinsip manajemen pengetahuan. Artikel ini juga menjelaskan solusi yang dapat diambil ketika mengalami masalah saat aplikasi tersebut.

- Artikel kelima dan keenam, memberikan contoh lain pelaksanaan konsep manajemen pengetahuan. Kedua artikel tersebut menjelaskan bahwa pimpinan perpustakaan sudah menyadari pentingnya berbagi pengetahuan tacit di antara para pustakawan.

- Artikel ketujuh, menjelaskan kemungkinan pemahaman masalah yang akan dihadapi oleh perpustakaan apabila di era modern perpustakaan belum menerapkan konsep manajemen pengetahuan. Artikel ini juga memberikan contoh solusi yang dapat dipilih dalam menghadapi permasalahan tersebut.

Berdasarkan uraian singkat tema dari masing-masing artikel dapat diketahui bahwa penerapan manajemen pengetahuan dalam bidang perpustakaan merupakan hal yang penting untuk dilakukan. Poonkothai (2016) mengatakan bahwa para profesional perpustakaan percaya program pendidikan, pelatihan profesional, komunitas pelaku pengetahuan, teknologi informasi, dan berbagi pengetahuan merupakan media penting dari manajemen pengetahuan di perpustakaan akademik. Manajemen pengetahuan akan membantu meningkatkan efisiensi operasional perpustakaan dan memenuhi kebutuhan pemustaka yang terus meningkat. Sebagai pekerja pengetahuan, para professional perpustakaan harus memperluas keahlian di luar manajemen koleksi. Pustakawan tidak lagi menjadi penjaga informasi, tetapi bertindak sebagai manajer pengetahuan, yang bertugas mengumpulkan dan menganalisis informasi strategis, melatih dan memberikan jasa konsultasi kepada pengguna.

Olajide (2015) mengatakan bahwa pustakawan sebagai profesi yang mengedepankan informasi dan pengetahuan membutuhkan pemahaman manajemen pengetahuan yang tepat agar mampu melakukan perubahan di perpustakaan. Islam et al. (2015) menjelaskan bahwa kegiatan manajemen pengetahuan di perpustakaan dapat dilakukan secara langsung (dengan cara mentoring, tutorial, pelatihan, storytelling, kelompok kerja) dengan menggunakan teknologi internet (email, website, search engine, telepon, telekonferensi, e-learning, repositori, multimedia, data mining, dan video). Pemanfaatan teknologi dalam manajemen pengetahuan di perpustakaan dibagi menjadi empat kelompok yaitu alat database (sistem), alat jaringan (internet), alat kolaboratif (sistem pertemuan elektronik, konferensi video, media sosial, sistem manajemen dokumen, email), dan alat pendukung (search engine, pemetaan pengetahuan). 
Wince (2018) mengatakan bahwa perpustakaan merupakan lembaga yang bertugas mengorganisasi informasi terekam dalam rangka memenuhi kebutuhan masyarakat. Menurut Iswanto (2019), sumber informasi yang ada di perpustakaan berupa koleksi tercetak dan digital. Informasi yang terekam tersebut menghasilkan informasi nonrekam dan pengetahuan. Perpustakaan dapat dikatakan sebagai lembaga sumber daya informasi dan pengetahuan. Manajemen pengetahuan perpustakaan juga dapat diterapkan di lembaga pendidikan. Olajide (2015) mengatakan bahwa dalam proses manajemen pengetahuan ada proses pendidikan yang mempengaruhi orang lain untuk menjadi lebih efisien dan efektif. Islam et al. (2015) menjelaskan alasan perpustakaan akademik perlu menerapkan manajemen pengetahuan yaitu untuk perbaikan layanan kepada pengguna dan peningkatan produktivitas pustakawan. Manajemen pengetahuan yang baik akan membuat pustakawan mampu mengambil keputusan berdasarkan informasi yang tepat.

\section{KESIMPULAN}

Jurnal IFLA Vol.46, No.1, Maret 2020 edisi Special Issue: Knowledge Management and Library Innovation in a Changing World berisi tema artikel yang membahas manajemen pengetahuan dengan perpustakaan. Tema tugas perpustakaan dalam manajemen pengetahuan memberi pemahaman bahwa tugas utama perpustakaan adalah mengelola pengetahuan bentuk cetak bukan pengetahuan tacit. Tema manajemen pengetahuan di perpustakaan akademik menjelaskan tentang pengelolaan pengetahuan eksplisit milik lembaga induknya. Tema restrukturisasi perpustakaan dengan menerapkan prinsip manajemen pengetahuan dapat diterapkan secara utuh untuk memenuhi kebutuhan informasi pengguna. Tema pasca-implementasi manajemen pengetahuan di perpustakaan menjelaskan penerapan kaidah manajemen pengetahuan pada metode kepemimpinan, tata koleksi hingga sistem layanan - sebagai alternatif solusi bagi perpustakaan. Tema jejaring perpustakaan kota berdasarkan konsep manajemen pengetahuan menjelaskan budaya saling menghimpun dan menyebarkan pengetahuan eksplisit diantara beberapa perpustakaan kota. Tema kegiatan berbagi pengetahuan dalam internal institusi mewakili pembahasan tentang berbagi pengetahuan dan cara mengevaluasi. Tema terakhir yaitu melemahnya fungsi perpustakaan bila tidak menerapkan konsep manajemen pengetahuan konvensional di perpustakaan.

\section{DAFTAR PUSTAKA}

Aghoghovwia, D.U. 2014. The Role of Libraries in Knowledge Management. IOSR Journal of Humanities and Social Science, 19(3): 55-57. https://doi.org/10.9790/0837-19325557.

Bedford, D.A.D., \& Lewis, J. 2015. Introduction to the Special Issue: Knowledge Management Models and Theories. Journal of Information and Knowledge Management, 14(4): 1-4. https://doi. org/10.1142/S0219649215020025.

Gonzalez, R.V.D. \& Martins, M.F. 2014. Knowledge Management: An Analysis from The Organizational Development. Journal of Technology Management and Innovation, 9(1): 131-47. https://doi. org/10.4067/s0718-27242014000100011.

Guest, G., MacQueen, K.M., \& Namey, E.E. 2012. Applied Thematic Analysis. California: SAGE.

Husain, S., \& Nazim. M. 2013. Concepts of Knowledge Management Among Library \& Information Science Professionals. International Journal of Information Dissemination and Technology, 3(4): 264-69. https://core.ac.uk/reader/83519182.

Islam, M.S., Siddike, M.A.K., Nowrin, S., \& Naznin, S. 2015. Usage and Applications of Knowledge Management for Improving Library and Information Services in Bangladesh. Journal of Information and Knowledge Management, 14(3): 1-10. https://doi.org/10.1142/S0219649215500264.

Iswanto, R. 2019. Problematika Layanan Digital Perpustakaan Institut Agama Islam Negeri Curup dalam Meningkatkan Pemanfaatan Karya Ilmiah Institusi. Tik Ilmeu : Jurnal Ilmu Perpustakaan dan Informasi, 3(1): 67. https://doi.org/10.29240/tik.v3i1.830. 
Labra, O., Castro, C., Wright, R., \& Chamblas, I. 2020. Thematic Analysis in Social Work: A Case Study. In Global Social Work - Cutting Edge Issues and Critical Reflections, 1-20. https://doi. org/10.5772/intechopen.89464.

Matthies, B., \& Coners, A. 2017. Document Selection for Knowledge Discovery in Texts: Framework Development and Demonstration. Journal of Information \& Knowledge Management, 16(4): 1-24. https://doi.org/10.1142/S0219649217500381.

Nowell, L.S., Norris, J.M., White, D.E., \& Moules, N.J. 2017. Thematic Analysis: Striving to Meet the Trustworthiness Oriteria. International Journal of Qualitative Methods, 16(1): 1-13. https://doi.org/10.1177/1609406917733847.

Olajide, A.A. 2015. Social Media Platform as A Knowledge Management Tool: Nigerian Librarians Experience. Journal of Information and Knowledge Management 14 (3): 1-9. https://doi. org/10.1142/S0219649215500185.

Poonkothai, R. 2016. Knowledge Management as An Important Tool in Organisational Management: A Review of Literature. International Journal of Information Technology and Library Science, 5(1): 9-14.

Riyadi, A., Mahmudah, A.R., \& Utami, D.B. 2016. Penerapan Knowledge Management: Oral History Penanganan Arsip Bencana Topan Haiyan di Filipina. BACA: Jurnal Dokumentasi dan Informasi, 37(2): 99-119.

Silverman, D. 2014. Interpreting Qualitative Data. 5th ed. London: SAGE.

Sudarsono, B., \& Imadianti, P. 2012. Pustakawan Memandang Knowledge Management. BACA: Jurnal Dokumentasi dan Informasi, 33(2).

Syahputra, H., \& Munadi, K. 2011. Knowledge Management untuk Pengurangan Risiko Bencana (Konsep dan Implementasi pada Pusat Riset Tsunami dan Mitigasi Bencana Unsyiah). Seminar Nasional Informatika (SEMNASIF), 1(5): 115-23.

Vaismoradi, M., Jones, J., Turunen, H., \& Snelgrove, S. 2016. Theme Development in Qualitative Content Analysis and Thematic Analysis. Journal of Nursing Education and Practice, 6(5). https://doi. org/10.5430/jnep.v6n5p100.

Vaismoradi, M., Turunen, H., \& Bondas, T. 2013. Content Analysis and Thematic Analysis: Implications for Conducting a Qualitative Descriptive Study. Nursing and Health Sciences, 15(3): 398-405. https://doi.org/10.1111/nhs.12048.

Wince, E. 2018. Benchmarking dalam Manajemen Sebuah Perpustakaan. Tik Ilmeu : Jurnal Ilmu Perpustakaan dan Informasi, 2(1): 23. https://doi.org/10.29240/tik.v2i1.435. 